University of Nebraska - Lincoln

DigitalCommons@University of Nebraska - Lincoln

Papers in the Earth and Atmospheric Sciences

Earth and Atmospheric Sciences, Department

7-14-2002

\title{
The Mount Feather Diamicton of the Sirius Group: an accumulation of indicators of Neogene Antarctic glacial and climatic history
}

\section{G. A. Wilson}

University of Oxford, Parks Road, Oxford OX1 3PR, UK

J. A. Barron

United States Geological Survey, MS 915, 345 Middleçeld Road, Menlo Park, CA

A. C. Ashworth

North Dakota State University, Fargo, ND

R. A. Askin

Byrd Polar Research Center, The Ohio State University, 1090 Carmack Road, Columbus, OH

J. A. Carter

School of Earth Sciences, Victoria University of Wellington, P.0. Box 600, Wellington, New Zealand

See next page for additional authors

Follow this and additional works at: https://digitalcommons.unl.edu/geosciencefacpub

Part of the Earth Sciences Commons

Wilson, G. A.; Barron, J. A.; Ashworth, A. C.; Askin, R. A.; Carter, J. A.; Curren, M. G.; Dalhuisen, D. H.; Friedmann, E. I.; Fyodorov-Davidov, D. G.; Gilichinsky, D. A.; Harper, M. A.; Harwood, David M.; Hiemstra, J. F.; Janecek, T. R.; Licht, K. J.; Ostroumov, V. E.; Powell, R. D.; Rivkina, E. M.; Rose, S. A.; Stroeven, A. P.; Stroeven, P.; van der Meer, J. J. M.; and Wizevich, M. C., "The Mount Feather Diamicton of the Sirius Group: an accumulation of indicators of Neogene Antarctic glacial and climatic history" (2002). Papers in the Earth and Atmospheric Sciences. 48.

https://digitalcommons.unl.edu/geosciencefacpub/48

This Article is brought to you for free and open access by the Earth and Atmospheric Sciences, Department of at DigitalCommons@University of Nebraska - Lincoln. It has been accepted for inclusion in Papers in the Earth and Atmospheric Sciences by an authorized administrator of DigitalCommons@University of Nebraska - Lincoln. 


\section{Authors}

G. A. Wilson, J. A. Barron, A. C. Ashworth, R. A. Askin, J. A. Carter, M. G. Curren, D. H. Dalhuisen, E. I.

Friedmann, D. G. Fyodorov-Davidov, D. A. Gilichinsky, M. A. Harper, David M. Harwood, J. F. Hiemstra, T. R. Janecek, K. J. Licht, V. E. Ostroumov, R. D. Powell, E. M. Rivkina, S. A. Rose, A. P. Stroeven, P. Stroeven, J. J. M. van der Meer, and M. C. Wizevich 


\title{
The Mount Feather Diamicton of the Sirius Group: an accumulation of indicators of Neogene Antarctic glacial and climatic history
}

G.S. Wilson ${ }^{a, *}$, J.A. Barron ${ }^{b}$, A.C. Ashworth ${ }^{c}$, R.A. Askin ${ }^{\text {d }}$, J.A. Carter ${ }^{\mathrm{e}}$, M.G. Curren ${ }^{f}$, D.H. Dalhuisen ${ }^{g}$, E.I. Friedmann ${ }^{\text {h}}$, D.G. Fyodorov-Davidov ${ }^{\mathrm{i}}$, D.A. Gilichinsky ${ }^{i}$, M.A. Harper ${ }^{\mathrm{e}}$, D.M. Harwood ${ }^{\mathrm{j}}$, J.F. Hiemstra ${ }^{\mathrm{k}}$, T.R Janecek ${ }^{\mathrm{f}}$, K.J. Licht ${ }^{1}$, V.E. Ostroumov ${ }^{\mathrm{i}}$, R.D. Powell ${ }^{\mathrm{m}}$, E.M. Rivkina ${ }^{\mathrm{i}}$, S.A. Rose ${ }^{\mathrm{j}}$, A.P. Stroeven ${ }^{\mathrm{n}}$, P. Stroeven ${ }^{\mathrm{g}}$, J.J.M. van der Meer $^{\mathrm{o}}$, M.C. Wizevich ${ }^{\mathrm{p}}$

a Department of Earth Sciences, University of Oxford, Parks Road, Oxford OX1 3PR, UK

b United States Geological Survey, MS 915, 345 Middlefield Road, Menlo Park, CA 94025, USA

c Department of Geosciences, North Dakota State University, Fargo, ND 58105, USA

d Byrd Polar Research Center, The Ohio State University, 1090 Carmack Road, Columbus, OH 43210, USA

e School of Earth Sciences, Victoria University of Wellington, P.O. Box 600, Wellington, New Zealand

f Antarctic Marine Geology Research Facility, Department of Geology, Florida State University, 108 Carraway Building, Tallahassee, FL 32306, USA

g Faculty of Civil Engineering, Delft University of Technology, Delft, The Netherlands

h Space Sciences Division, NASA Ames Research Center, Mail Code 245-3, Moffett Field, CA 94035, USA

i Institute of Soil Science and Cryology, Russian Academy of Sciences, Puschino, Moscow Region 142292, Russia

j Department of Geosciences, University of Nebraska, 214 Bessey Hall, Lincoln, NE 68588, USA

k Department of Geography and Topographic Science, University of Glasgow, Glasgow G12 8QQ, UK

${ }^{1}$ Department of Geology, Indiana University, Purdue University Indianapolis, 723 West Michigan Street, Indianapolis, IN 46202, USA

m Department of Geology and Environment Geosciences, Northern Illinois University, De Kalb, IL 60115, USA

n Department of Quaternary Research, Stockholm University, S-106 91 Stockholm, Sweden

- Department of Geography, Queen Mary and Westfield College, University of London, Mile End Road, London E1 4NS, UK

$\mathrm{p}$ Department of Geological Sciences, Cornell University, Ithaca, NY 148533, USA

\begin{abstract}
A paucity of data from the Antarctic continent has resulted in conflicting interpretations of Neogene Antarctic glacial history. Much of the debate centres on interpretations of the glacigene Sirius Group strata that crop out as discrete deposits along the length of the Transantarctic Mountains and in particular on its age and the origin of the siliceous microfossils it encloses. Pliocene marine diatoms enclosed within Sirius Group strata are inferred to indicate a dynamic East Antarctic ice sheet that was much reduced, compared with today, in the early-middle Pliocene and then expanded again in the late Pliocene. However, the geomorphology of the Dry Valleys region is interpreted to represent a relatively long-lived (middle Miocene-recent) and stable polar climatic regime similar to that of today. The
\end{abstract}

* Corresponding author, Present address: Department of Geology, University of Otago, PO Box 56, Dunedin, New Zealand. E-mail address: gary.wilson@stonebow.otago.ac.nz (G.S. Wilson). 
Mount Feather Diamicton infills a palaeovalley at ca. $2500 \mathrm{~m}$ on the NE flank of Mount Feather in the Dry Valleys region and has been included within the Sirius Group. We obtained four shallow cores (COMRAC 8, 9, 10 and 11) from beneath the permafrost boundary in the Mount Feather Diamicton in order to understand its origin and relationship with the surrounding landscape. Detailed studies of these cores (stratigraphy, sedimentology, palaeontology, micromorphology, petrography and fabric) have yielded new data that demonstrate a much more complex climatic and glacial history for the Mount Feather Diamicton than in previous interpretations. The data indicate that the Mount Feather Diamicton was deposited beneath a wet based glacier fed from a larger ice sheet behind the Transantarctic Mountains. It is, however, unlikely that this ice sheet overtopped Mount Feather (2985 m). A near-in situ non-marine diatom assemblage was recovered from $90 \mathrm{~cm}$ depth in COMRAC 10 and indicates a maximum depositional age of Late Miocene for the Mount Feather Diamicton. A subsequent glacial episode has distributed a boulder blanket across the surface of the diamicton. Other post-depositional processes include drying, infilling of surface layers with aeolian sediment, and the development of melt-water runnels. We interpret these combined data to indicate the persistence of more temperate climatic and glacial conditions in the vicinity of Mount Feather until at least the Late Miocene. (C) 2002 Elsevier Science B.V. All rights reserved.

Keywords: Antarctica; ice sheet; Sirius Group; climate; coring; microfossils

\section{Introduction}

Sirius Group strata are the focus of intense debate surrounding Neogene Antarctic glacial history (e.g. Burckle and Pokras, 1991; Webb and Harwood, 1991; Kennett and Hodell, 1993; Sugden et al., 1993; Wilson, 1995; Kellogg and Kellogg, 1996; Barrett et al., 1992, 1997; Miller and Mabin, 1998). They, along with glacigene strata in the Prince Charles Mountains (McKelvey and Stephenson, 1990; Hambrey and McKelvey, 2000), comprise the extent of the currently known Cenozoic stratigraphic record exposed on the Antarctic craton. Mayewski (1975) mapped and correlated Cenozoic glacigene strata throughout the Transantarctic Mountains and proposed that these deposits all be grouped within the Sirius Formation (later elevated to Group by McKelvey et al., 1987, 1991). However, it was not until Harwood (1983) discovered reworked Pliocene marine diatoms enclosed within the diamict beds of the Sirius Group strata, that the significance of the Sirius Group was realised with respect to Neogene Antarctic glacial history. The Sirius Group, Webb et al. (1984) claimed, was younger than the reworked Pliocene marine diatoms it contained. The diatoms, along with terrestrial microfossils and macrofossils (Harwood, 1986; Prentice et al., 1986; Webb et al., 1986; Webb and Harwood, 1987), and the temperate nature of the glacial strata (McKelvey et al., 1984) led Webb et al.
(1984) and Webb and Harwood (1991) to postulate that the East Antarctic ice sheet, while being present in Antarctica for more than $30 \mathrm{Myr}$, was, until recently (ca. 2.5 Ma), a dynamic feature, waxing and waning under a more temperate climatic and glacial regime. However, geomorphic analysis of the Dry Valley landscape is interpreted to indicate that the Dry Valleys region has been unmodified in a stable and hyper-arid climate for at least the last 14 Myr (Sugden et al., 1993; Sugden, 1999; Marchant et al., 1993, 1996) and that it does not record any evidence of the more temperate climate and glacial waxing and waning suggested by Webb et al. (1984).

A flurry of international meetings and publications has recently seen opposing fractions level criticism on the techniques, findings, and reproducibility of data sets of some workers' investigations into the record of Neogene East Antarctic glacial history (e.g. Wilson, 1995; Burckle and Potter, 1996; Burckle et al., 1996; Sugden, 1996; Barrett et al., 1997; Stroeven et al., 1998). Key issues relating to Sirius Group strata concern the nature of the ice depositing the Sirius Group strata and whether it is linked to local or continental scale glaciation (e.g. Stroeven and Prentice, 1997) and the age and origin of the reworked microfossils. Barrett et al. (1992) demonstrated that the marine diatoms were Pliocene in age. However, the mode of their incorporation into the strata is still questioned. Some workers sug- 
gest an aeolian origin (e.g. Kellogg and Kellogg, 1996; Stroeven et al., 1996; 1998; Barrett et al., 1997). However, Harwood and Webb (1998) demonstrated that this was unlikely for Pliocene diatoms recovered from the Beardmore Glacier Sirius Group strata. However, the discrete Dry Valleys Sirius Group units (e.g. Brady and McKelvey, 1979; Barrett and Powell, 1982; Stroeven et al., 1996) are quite different to the stratified Sirius Group formations that crop out to the south in the Beardmore Glacier and Reedy Glacier regions (e.g. Mercer, 1968; Denton et al., 1991; Webb et al., 1996; Wilson et al., 1998c). Sirius Group strata from the Beardmore Glacier and Reedy Glacier regions have more affinity to the Valley fill strata recovered in the CIROS-2 core (Ferrar Fjord; Barrett and Hambrey, 1992) and DVDP-10 and -11 cores (Taylor Valley; Ishman and Rieck, 1992).

Advocates of a dynamic history of the East Antarctic ice sheet point to the thick $(>100 \mathrm{~m})$, stratified, lower elevation $(<2000 \mathrm{~m})$ occurrences of the Sirius Group from the central and southern Transantarctic Mountains, that include varying glacial, glacimarine, and glacilacustrine facies, as their stratotype for interpretations of the significance of the Sirius Group (e.g. Mercer, 1968; Webb et al., 1996; Wilson et al., 1998c). Advocates of a stable history of the East Antarctic ice sheet concentrate on the thin $(<50 \mathrm{~m})$, mostly massive, high elevation, glacial, single facies occurrences of the Sirius Group from southern Victoria Land as their stratotype for interpretations of the significance of the Sirius Group (e.g. Denton et al., 1984; Sugden et al., 1993; Burckle and Potter, 1996; Kellogg and Kellogg, 1996; Marchant et al., 1996; Barrett et al., 1997; Stroeven et al., 1998). Despite an eloquent theory proposed by Webb (1994), the exact relationship, in genesis and age, of these two different generalised facies associations of the Sirius Group will not be solved until their composition and origin is better understood.

\subsection{The Mount Feather coring project}

The Dry Valleys area offers some common ground for both sides of the debate. Much of the evidence that has been compiled and inferred to be indicative of cold polar desert climatic stability is from studies of the geomorphic development of the Dry Valleys region (e.g. Marchant et al., 1993, 1996; Sugden et al., 1993; 1995; Sugden, 1999). Also, within the Dry Valleys region are glacial deposits that have been assigned to the Sirius Group by various workers (e.g. Mayewski, 1972; Denton et al., 1991; Webb and Harwood, 1991; Stroeven et al., 1996). A coring project $($ COMRAC $=$ coring for microbial records of Antarctic climate) was undertaken to investigate the Sirius Group deposit on Mount Feather (Mount Feather Diamicton; Wilson and Barron, 1998; Fig. 1). Primary objectives of drilling were (1) to better understand one of the Sirius Group deposits in the Dry Valleys and its enclosed microfossils; (2) to obtain samples from beneath the permafrost boundary; and (3) to understand the relationship of the Mount Feather Diamicton to other deposits in the Dry Valleys region and to other Sirius Group deposits. The Mount Feather Diamicton was chosen because of its high altitude $(2985 \mathrm{~m})$, the fact that it had previously been reported to contain Pliocene marine microfossils, its proximity to reputedly old landform features, and its proximity to the current East Antarctic ice sheet.

Four cores were recovered from the Mount Feather Diamicton (Figs. 1 and 2, COMRAC 8: $3.20 \mathrm{~m}$, COMRAC 9: $1.95 \mathrm{~m}$, COMRAC 10: $2.50 \mathrm{~m}$, and COMRAC 11: $1.00 \mathrm{~m}$ ). The cores were collected using a coring system developed at the Institute of Soil Science and Photosynthesis of the Russian Academy of Sciences, specifically for biologic studies of permafrost (Wilson et al., 1996). The device uses no drilling fluid, and relies on the frozen condition of the core to maintain stratigraphic integrity and to prevent down-hole contamination. In order to make the material available for a wider community to address questions of commonality and openness in sampling and scientific approach, the cores were sealed after collection in Antarctica and opened again in a class 100 cleanroom constructed at the Antarctic Core Repository at Florida State University (Wilson et al., 1998a). The cores were described and samples taken for investigators in a workshop 


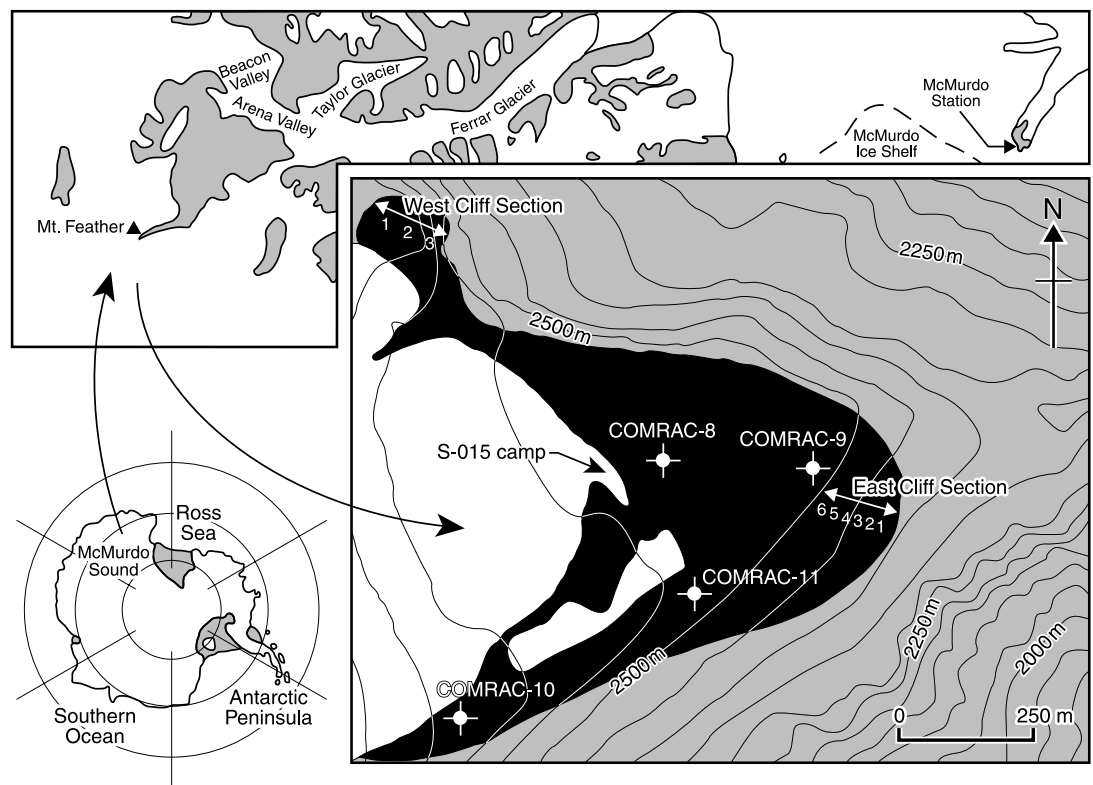

Fig. 1. Location of Mount Feather, southern Victoria Land. Map of the Mount Feather Diamicton (Sirius Group) deposit (black), showing the drilling camp, locations of the four drill-holes (COMRAC 8-11) and sampled outcrop section.

setting (Wilson and Barron, 1998). Samples had been offered to the wider community and were distributed to 30 investigators, of whom 20 submitted detailed reports of methods of analysis and results in the core workshop proceedings volume (Wilson and Barron, 1998).

\section{The Mount Feather Diamicton}

\subsection{Geomorphology}

The Mount Feather Diamicton (Wilson and Barron, 1998) is a semi-lithified diamicton that crops out at $2500 \mathrm{~m}$ altitude on the NE ridge of Mount Feather (Fig. 1). It unconformably overlies the Feather Conglomerate and Lashly Formation of the Beacon Supergroup. The diamicton thickens to the SE, infills a small palaeovalley, and is disconformably overlain in part by a younger glacial lag deposit comprising mostly angular dolerite boulders (Fig. 4b). The unit was first fully described by Brady and McKelvey (1979) who interpreted it to be an alpine glacier deposit. It had earlier been assigned to the Sirius
Formation (now Group) by Mayewski (1972). From field observation and coring (Fig. 2), the deposit can be subdivided into two main stratigraphic units; a ca. $40 \mathrm{~m}$ thick lower unit comprising disconformity-bounded, decimetre-bedded, ice-cemented diamicton with rounded cobbles and occasional horizons of ice (up to $50 \mathrm{~cm}$ thick), and an upper (30-50 cm thick) unit, very similar in character, but dry and comprising additional exotic minerals, salts and secondary infilling matrix accumulating above the permafrost boundary. Where exposed, the surface of the diamicton is marked by glacial grooves and striae, which are consistent with fabric directions derived from the long axis directions of clasts within the diamicton (Fig. 3). Near its perimeter and on steeper slopes, the diamicton surface contains distinct melt-water runnels (Fig. 4c), derived from either snowmelt or melt-out from the permafrost active layer.

\subsection{Lithofacies}

\subsubsection{Diamict}

Diamict is the most common facies recovered in 
G.S. Wilson et al./ Palaeogeography, Palaeoclimatology, Palaeoecology 182 (2002) 117-131

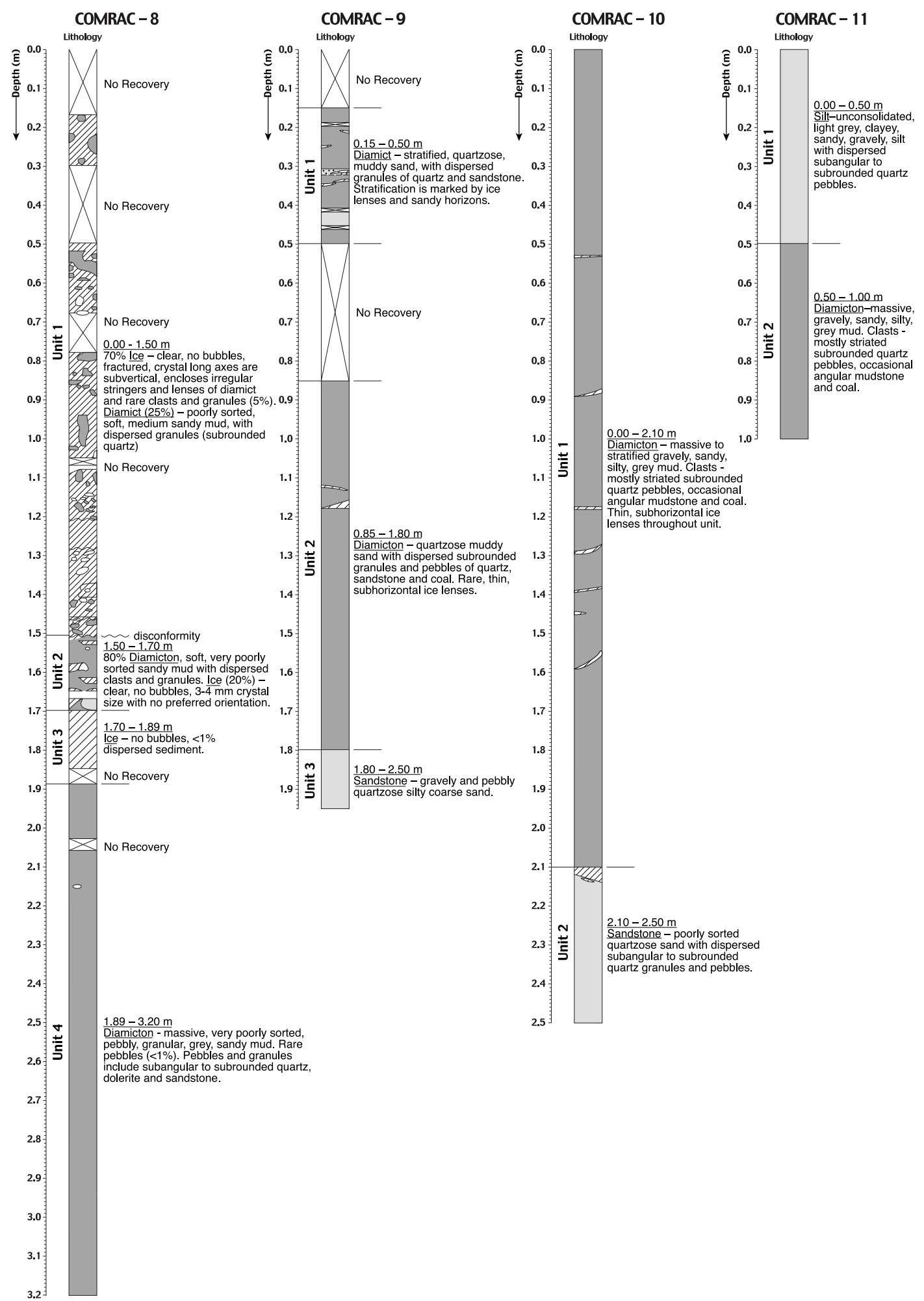

Fig. 2. Lithologic descriptions of COMRAC 8-11 drill-cores. 
Striations

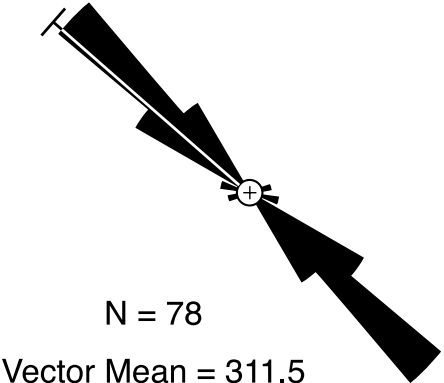

Clast Fabric

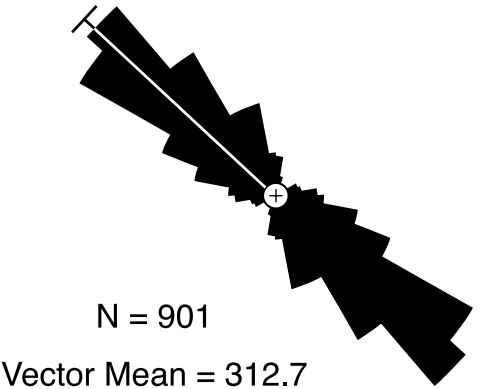

Fig. 3. Rose diagrams of striae directions and clast fabric from the Mount Feather Diamicton.

the COMRAC cores. It is generally massive but occasionally stratified (Fig. 4d-g), and uniform in its texture and composition and is only subdivided on the basis of lithification. Ice lenses are relatively common. Clasts are mostly rounded quartz with minor sandstone and occasionally dolerite and range from 1 to $15 \mathrm{~cm}$ in diameter. Quartz and dolerite clasts are occasionally striated. Texture, mineralogy and micromorphology of diamict samples were determined by pointcounts of thin sections vacuum-impregnated with blue dye (Dickinson, 1998), sedimentary grain size analysis (Barrett, 1998) and resin-impregnated thin sections (van der Meer et al., 1998). The diamict facies is generally sandy and comprises mostly framework grains of quartz $(15-30 \%)$ and sedimentary rock fragments $(10-15 \%$, including coal), ice-filled pore spaces $(5-25 \%)$ and lesser concentrations of feldspar $(<5 \%)$ and igneous rock fragments $(<5 \%)$, with a clay matrix $(15-$ $30 \%$ ).

The diamict mineralogy is consistent with local derivation, primarily from Beacon Supergroup sediments. The high sand content, uniform matrix texture and composition is interpreted by Barrett (1998) as a basal glacial deposit with little or no influence from running water. However, micromorphologic examination of two intervals from the cores shows rotational structures and plasmic fabrics indicative of temperate subglacial deposition and/or subglacial reworking (van der Meer et al., 1998). Microscopic illuviation features were also observed by van der Meer et al. (1998) (Fig. 5a,b) and these may have resulted, in part, from post-depositional groundwater percolation. Pore shape is variable and ranges from small cracks, which parallel grain surfaces, to large and equidimensional pores that show no obvious pattern of variation in space and depth.

\subsubsection{Ice}

Ice occurs in all cores as subcontinuous irregular subhorizontal, 0.1-1-cm-thick lenses. Ice lenses are generally clear with no bubbles or included sediment. The upper $1.9 \mathrm{~m}$ of COMRAC $8 \mathrm{com}$ prises more than $70 \%$ ice. The ice encloses clasts, lenses and stringers of unconsolidated diamict $(25 \%)$. Seven percent of the ice contains dispersed mud and granules of quartz, coal and sandstone. Where sediment-free, the ice is clear, lacks bubbles and comprises uniform crystals that are 0.3 $0.4 \mathrm{~cm}$ in size and do not appear to show any preferred orientation.

\subsubsection{Sand}

Less than $10 \%$ of the lithofacies encountered in the COMRAC cores is massive, quartzose, poorly sorted medium sand to sandstone. The sand comprises $1 \%$ granules and rare dispersed subrounded to subangular pebbles of quartz.

\subsubsection{Pebbly silt}

The upper $50 \mathrm{~cm}$ of COMRAC 11 comprises an unconsolidated clayey, sandy, gravely silt with $2 \%$ angular to well-rounded quartz pebbles. Pebbles are up to $6 \mathrm{~cm}$ in diameter and are occasionally striated. 


\subsection{Stratigraphy}

COMRAC 8 is subdivided into four units on the basis of lithofacies (Fig. 2). Unit 1 $(0-1.50 \mathrm{~m})$ directly underlies the angular dolerite boulder lag and comprises $70 \%$ ice with $25 \%$ diamict distributed as rounded clasts, lenses and stringers filling conduits and pipes within the ice (Fig. 4h). The remaining $5 \%$ of the unit comprises dispersed subangular to subrounded quartz granules and pebbles. Eighty percent of the uppermost $50 \mathrm{~cm}$ of the core was not recovered intact. Unit $2(1.50$ $1.70 \mathrm{~m}$ ) is separated from the overlying Unit 1 by a sharp irregular contact. It is a 20 -cm-thick icecemented granular diamiction with dispersed angular to subangular quartz and dolerite pebbles. Unit $3(1.70-1.89 \mathrm{~m})$ is a 19 -cm-thick band of clear ice, which has a gradational contact with the underlying grey muddy diamict (Unit 4; $1.89 \rightarrow 3.20 \mathrm{~m}$ ). Unit 4 contains rare thin ice lenses but is mostly massive. Granules and pebbles are commonly quartz and less commonly dolerite and sandstone. Pebbles are well-rounded and occasionally striated.

COMRAC 9 is subdivided into three units (Fig. 2). The upper two units are both diamicts. The uppermost $15 \mathrm{~cm}$ was not recovered and units 1 and 2 are separated by a $35-\mathrm{cm}$ interval that was not recovered. Unit $1(0.15-0.50 \mathrm{~m})$ is a quartzose sandy diamict with dispersed subrounded granules and pebbles of quartz and occasionally sandstone. One to two-centimetre-thick ice lenses and horizons are common. Unit 2 is a quartzose sandy diamiction with dispersed subrounded granules and pebbles of quartz and occasionally sandstone and coal, but with only two ice lenses; one at $1.12 \mathrm{~m}$ depth and the other at 1.17 $\mathrm{m}$ depth. Unit 3 is a fine to medium sandstone separated from the overlying diamict by a sharp contact. The sand is occasionally gravely and pebbly. Pebbles are angular to subangular quartz and coal.

COMRAC 10 comprises only two units. Unit 1 $(0-2.1 \mathrm{~m})$ is a grey muddy diamiction. Pebbles are mostly subangular to subrounded striated quartz with occasional angular mudstone and coal fragments. Thin $(<1 \mathrm{~cm})$ discontinuous ice lenses are dispersed throughout this unit. The diamiction is separated from an underlying sand (Unit 1) by a 2-4-cm-thick clear ice band. Unit $(2.10-2.50 \mathrm{~cm})$ 2 is a massive poorly sorted medium-grained quartzose sand with dispersed rare subangular to subrounded quartz pebbles.

The upper $50 \mathrm{~cm}$ of COMRAC 11 is an unconsolidated clayey, sandy, gravely silt with $2 \%$ angular to well-rounded quartz pebbles (Unit 1). Pebbles are up to $6 \mathrm{~cm}$ in diameter and are occasionally striated. Below is a grey muddy diamiction (Unit 2;0.50 $\rightarrow 1.00 \mathrm{~m}$ ) similar to that of Unit 1 of COMRAC 10.

\subsection{Microfossils}

Diatoms, palynomorphs, phytoliths, and viable microbes were recovered from the cores and surface samples of the Mount Feather Diamicton (Fig. 5).

Diatoms were recovered from diamicton samples by a three-step procedure (Harwood and Rose, 1998; Harwood et al., 1986). First, the samples were suspended in a distilled water and calgon solution. Once disaggregated, the resulting slurry was elutriated in a 2-m-high cylinder of sub-micronfilter water and separate hydrodynamic fractions were drawn off by siphoning. Siphoned fractions were then subdivided according to density using a sodium polytungstate solution. Diatom frustules were also recovered during extractions of phytoliths at a separate laboratory (Harper, 1998). The diatoms recovered from the core samples (Fig. 5) belong to two assemblages: (1) a Cenozoic, mostly reworked marine assemblage comprising rare fragments of Coscinodiscus/Thalassiosira? and small fragments of Thalassiothrix/Thalassionema? and Eucampia (Fig. 5k,1) with less common fragments of Coscinodiscus, Thalassiosira, or Stephanopyxis, and (2) an excellently preserved nearly in situ non-marine assemblage from $90 \mathrm{~cm}$ depth in COMRAC 10 dominated by Anomoeoneis costata (Fig. 5i). The presence of Stephanodiscus sp. (Fig. 5n) in the assemblage from $90 \mathrm{~cm}$ in COMRAC 10 indicates a maximum age of Late Miocene (Krebs and Platt, 1995) for the Mount Feather Diamicton.

Abundant generally well-preserved phytoliths were recovered from throughout the COMRAC 


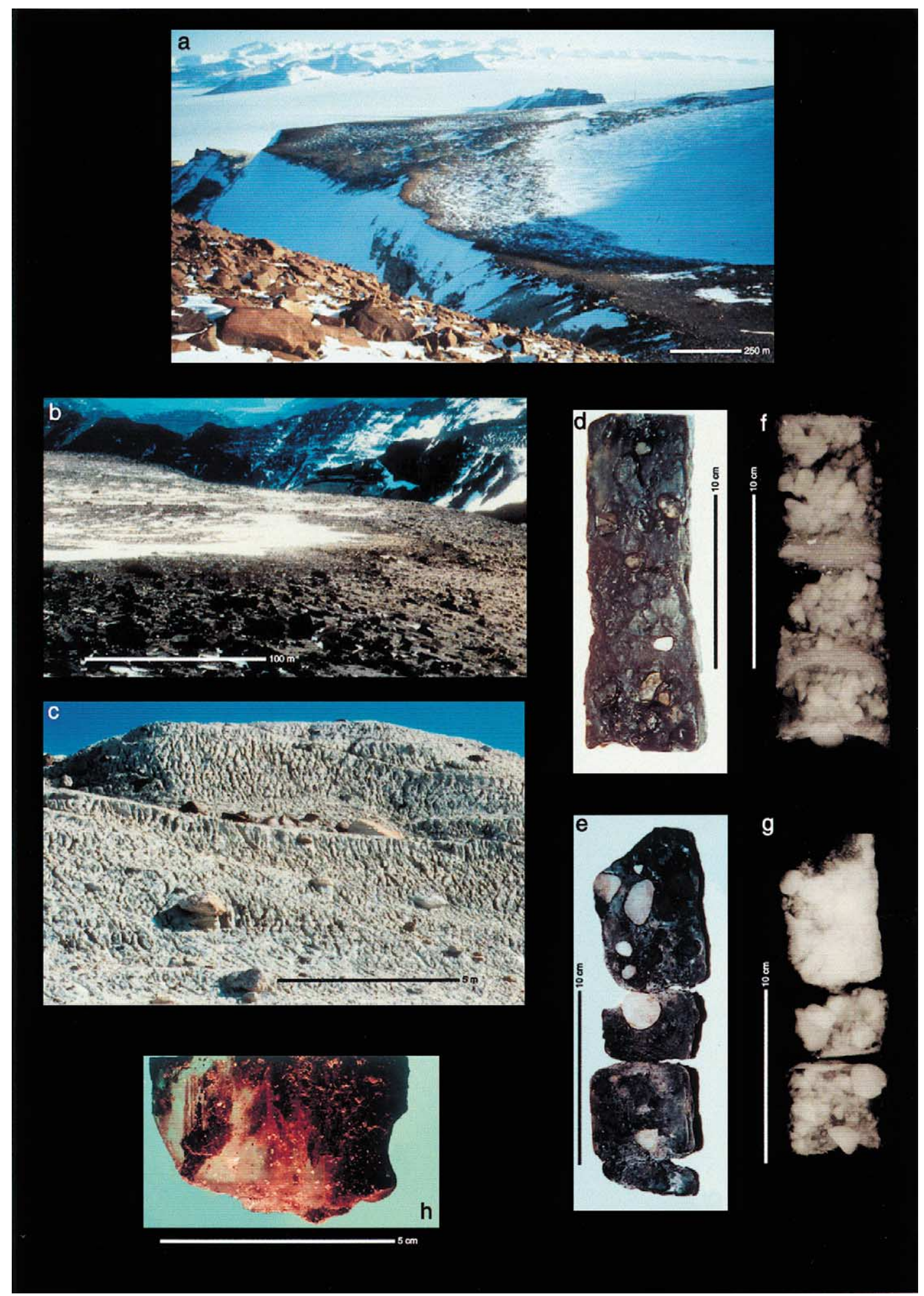


cores in all samples examined (Carter, 1998a; Fig. $5 f-h)$. Samples were prepared using hot $\mathrm{H}_{2} \mathrm{O}_{2}$ treatment, ultrasonic disaggregation, sieving and digestion via 'Schulzes Solution'. Forms recovered include polyhedral, opaque, elongate, jigsaw, cubic, multifaceted and spherical. All these forms most likely originate from trees and shrubs and from several sources and periods. Polyhedral, opaque, elongate and jigsaw phytoliths have a strong affinity to forms recovered from nearby Beacon Supergroup sediments (Carter, 1999). The source is unknown for other forms, although the spherical phytoliths are similar to those reported by Kondo et al. (1994) and Carter (1998b) in Neogene glacigene sediments in the Ross Sea and they may have a common source to the spherical phytoliths recovered in the COMRAC cores.

Abundant to sparse terrestrial palynomorphs were also recovered from all COMRAC core samples examined (Askin, 1998; Fig. 5c-e). Processing included mineral dissolution in hydrochloric and hydrofluoric acids, followed by oxidation in nitric acid and heavy liquid separation. No presumed contemporaneous palynomorphs were observed, which suggests a non-vegetated area, at least in the immediate vicinity and up-wind, upvalley source area of the glacier depositing the Mount Feather Diamicton. All recovered fossil spores and pollen were derived from erosion and recycling of Triassic sediments equivalent to the Lashly Formation (upper Victoria Group, Beacon Supergroup). Among the many diagnostic forms are Anapiculatisporites pristidentatus, Cadargasporites baculatus, Cadargasporites granulatus, $\mathrm{Ca}$ dargasporites senectus, Craterisporites rotundus, Limbosporites denmeadii, Polycingulatisporites densatus and Striatella seebergensis. In general, the yellow-orange to orange-brown colour of the spores and pollen suggests low thermal maturation and a provenance from sediments with lit- tle to no thermal effects from dolerite intrusion. Current exposures of Lashly Formation in southern Victoria Land are commonly intruded by dolerite and palynomorphs have undergone higher thermal alteration (Kyle, 1977; Kyle and Schopf, 1982). Provenance for most of the fossil spores and pollen recovered from the Mount Feather Diamicton may be inland of the present Transantarctic Mountains, and these relatively lightcoloured Triassic palynomorphs may attest to the lack or scarcity of dolerite in that region. Alternatively, a more local source of the relatively dolerite-free sediments of the uppermost Lashly Formation is possible, but for only some of the youngest reworked Triassic assemblages. A few reworked somewhat darker specimens indicate a local origin from dolerite-intruded sediments.

The COMRAC 8 core also contained viable bacteria, including anaerobes (Wilson et al., 1998b). From collection, cores and samples were sealed in plastic tubing and maintained at $-20^{\circ} \mathrm{C}$ to prevent contamination and renewed microbial activity in unmonitored settings. The number of bacteria varied, up to $10^{2}-10^{3} \mathrm{~g}^{-1}$ by plate counts and up to $10^{5} \mathrm{~g}^{-1}$ by fluorescence. Enzyme activity, also a sign of biological activity, was present in most preparations. These bacteria most likely originated from the time of glacial emplacement of the deposit and are the oldest viable bacteria discovered in Antarctica.

Stroeven et al. $(1996,1998)$ and Barrett et al. (1997) reported a decrease in microfossil content with depth. We did not observe any variation in microfossil distribution with depth, except for a single sample from $90 \mathrm{~cm}$ depth in COMRAC 10, which yielded a greater abundance of diatom frustules (Harwood and Rose, 1998). Like Barrett et al. (1997) we also found the microfossils to be very rare and examination of large thin sections from two intervals of the cores (van der Meer et al., 1998) failed to locate any microfossils and

Fig. 4. (a) The Mount Feather Diamicton perched on Beacon Supergroup strata that comprise the NE ridge of Mount Feather. The drilling camp is located on the snow apron in the middle ground. (b) Dolerite lag that is draped over the Mount Feather Diamicton (see discussion in text). (c) Eastern cliff section (type section) of the Mount Feather Diamicton showing distinctive melt-water runnels. Section is about $40 \mathrm{~m}$ thick. ( $\mathrm{d}$ and e) Representative photographic images of intact segments of COMRAC cores. (f and g) X-ray images of the same intact core segments highlighting stratification and ice lenses. (h) Section from $0.5 \mathrm{~m}$ depth in the COMRAC 8 core with sediment-filled pipes and conduits (see discussion in text). 


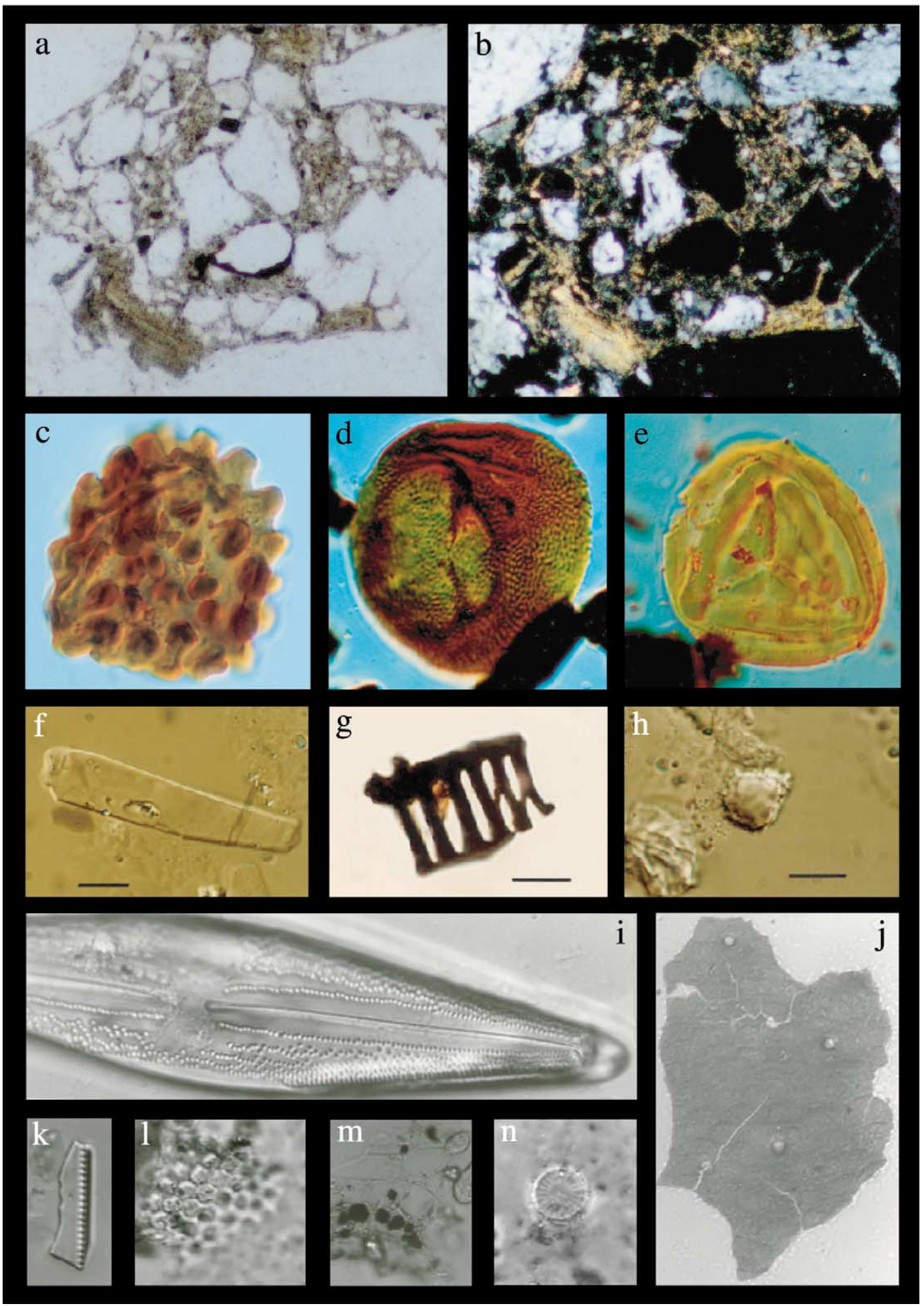


hence identify the exact location of microfossils within the sedimentary framework. We have ruled out any down-hole contamination during core recovery because all the COMRAC cores were recovered from beneath the permafrost boundary. Core segments are ice-cemented with ice filling any pore space and all cores were recovered frozen and without a drilling fluid.

\section{A glacial and climatic repository}

The Mount Feather Diamicton is a repository for discrete palaeoenvironmental information prior to its deposition, the glacial regime during its deposition, and post-depositional glacial and climatic episodes (Fig. 6). The deposit on the NE flanks of Mount Feather lies within a SE facing palaeovalley and comprises a diamicton up to $40 \mathrm{~m}$ thick with several disconformity-bounded beds possibly representing progressive glacial infilling of the palaeovalley. Sediments included in the Mount Feather Diamicton originate mostly from nearby Beacon Supergroup sediments and Ferrar Dolerite rocks. Elements of the palynomorph and phytolith assemblages distributed throughout the deposit were also derived by erosion of the nearby Beacon Supergroup rocks. Sedimentary micro- and macrofabrics and micromorphology demonstrate that the Mount Feather Diamicton was deposited under a SE flowing wetbased glacier.

The sedimentology and geomorphic setting indicate that the glacier that deposited the Mount Feather Diamicton was of regional extent. How- ever, palynomorphs of low thermal maturity, phytoliths and possibly diatoms of the Mount Feather Diamicton are not derived from the nearby Beacon Supergroup and Ferrar Dolerite rocks. They were derived from 'behind' the present Transantarctic Mountains. Present exposures of the Lashly Formation (Beacon Supergroup) yield palynomorphs of higher thermal maturity (Askin, 1998). Spherical phytoliths, like their counterparts in McMurdo Sound cores, must have been derived from post-Beacon age strata possibly to the west, beneath the present East Antarctic ice sheet. Cenozoic marine diatoms may also originate from post-Beacon marine strata behind the Transantarctic Mountains and represent times of marine productivity in that vicinity (i.e. before the East Antarctic ice sheet formed, or during times of glacial retreat). However, their rarity in this study prevents any certain conclusion with respect to their origin or age. All these exotic particles were transported from further afield and deposited along with locally derived sediment by the same SE flowing glacier.

The micromorphology of the diamiction indicates that the climate during glacial deposition was warmer than today. Especially the turbate structures, plasmic fabric, illuviation signatures, and the microfabric of sand particles (van der Meer et al., 1998; Stroeven et al., in press) reveal that the glacier was wet-based and likely operated in a subpolar climate. The near-in situ freshwater diatom assemblage in COMRAC 10 is consistent with this interpretation because it represents interglacial times during deposition of the Mount Feather Diamicton.

Fig. 5. Representative photomicrographs of micromorphology of thin sections and microflora from the Mount Feather Diamicton. ( $\mathrm{a}$ and $\mathrm{b}$ ) Illuviated clay in a grain embayed in COMRAC 9-3. The fine-grained cutan is exclusively the result of deposition by running water. Note faint lamination which is also visible in the well-developed plasmic fabric (field of view $=2 \mathrm{~mm}$ ). $\mathrm{a}=$ Plane polarised light, $\mathrm{b}=$ cross-polarised light. (c-e) Selected recycled Triassic spores from the Mount Feather Diamicton (magnification approximately $\times 1400$ ); (c) Anapiculatisporites pristidentatus Reiser and Williams from COMRAC 8-18; (d) Cadargasporites senectus de Jersey and Hamilton from COMRAC 9-8; (e) Striatella seebergensis Mädler from COMRAC 9-8. (f-h) Selected phytoliths from the Mount Feather Diamicton (scale bar $=10 \mu$ ); (f) jigsaw phytolith from COMRAC 10-2; (g) etched polyhedral phytolith from COMRAC 10-1; (h) elongate phytolith from COMRAC 10-7. (i, k, 1 and n) Selected diatoms from the Mount Feather Diamicton; (i) Anomoeoneis costata, non-marine diatom from COMRAC 10-5 (field of view $=25 \mu$ ); $(\mathrm{k})$ fragment of marine diatom Thalassiothrix or Thalassionema from COMRAC 10-13 (field of view $=4 \mu$ ); (1) fragment of marine centric diatom of Coscinodiscus, Thalassiosira, or Stephanopyxis from COMRAC 10-13 (field of view $=6 \mu$ ). ( $\mathrm{j}$ and $\mathrm{m}$ ) Selected photomicrographs of organic residues from the Mount Feather Diamicton; (j) leaf tissues with guard cells from COMRAC 10-5 (field of view $=20 \mu) ;(m)$ organic tissues from COMRAC $10-5$ (field of view $=15 \mu$ ); (n) staphanodiscus sp. from COMRAC 10-5 (field of view $=4 \mu$ ). 


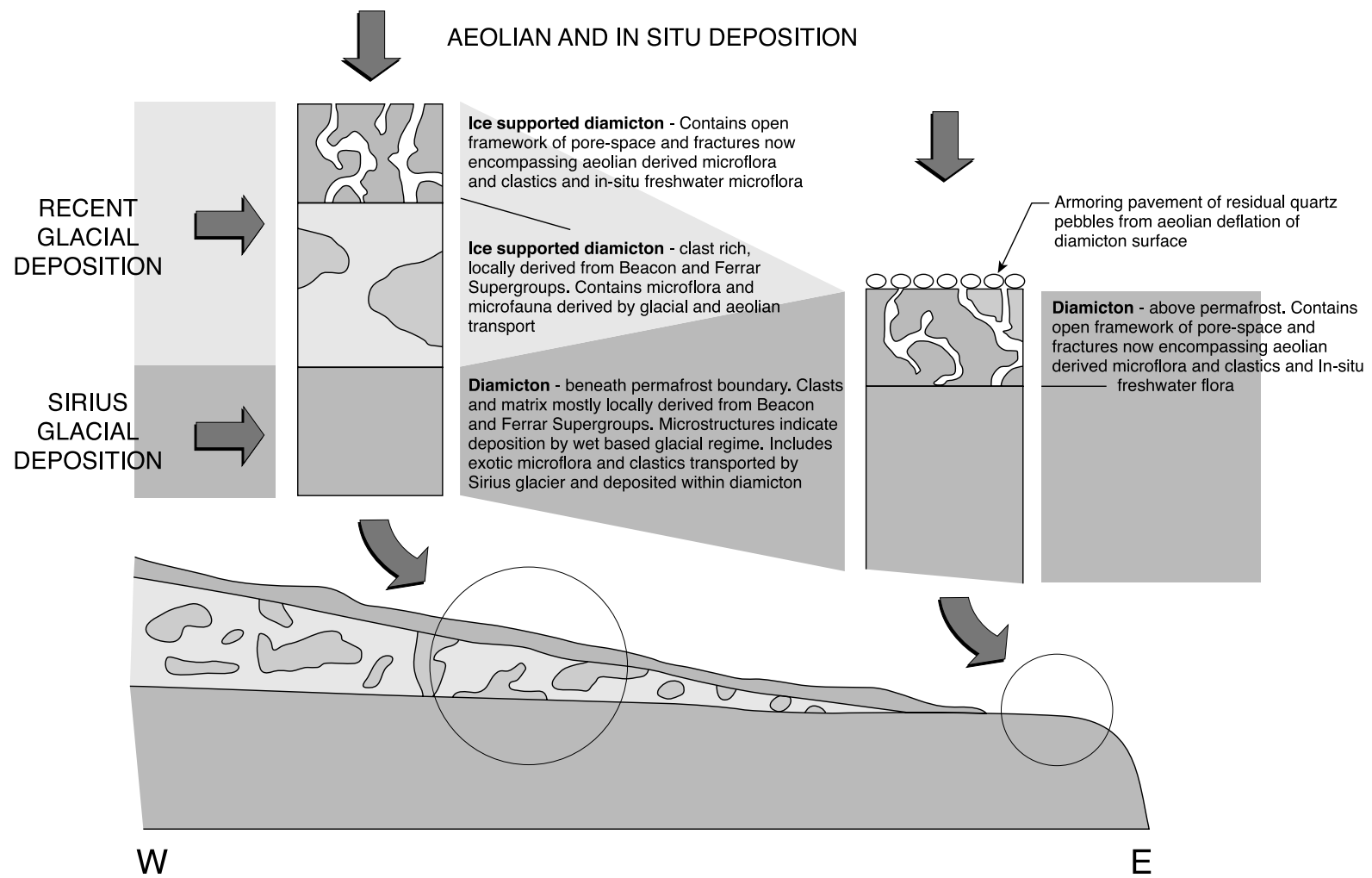

Fig. 6. Schematic diagram of Mount Feather Diamicton and origin of particles enclosed within the diamicton and it's constituent stratigraphic layers and the climatic episodes and glacial regimes these might represent.

Where exposed, the surface and immediate subsurface $(<0.5 \mathrm{~m})$ of the Mount Feather Diamicton are dry and often protected by a salt-cemented crust resulting from long exposure to a dry environment. Glacial grooves and striae from a subsequent glacial event also mark the diamicton surface. To the west the diamicton surface is blanketed by a dolerite-rich ice-supported glacial lag deposit that thickens westward to $>2 \mathrm{~m}$ (Fig. 4b). Within this lag, ice contains sedimentfilled pipes and conduits indicating active melting inside the basal layer of the glacier (Fig. 4h). A prior study (Barrett et al., 1997) recovered a much higher concentration of small, predominantly fresh-water diatoms at the surface of the Mount Feather Diamicton, within the near-subsurface (above the permafrost boundary), and on nearby surfaces. This demonstrates that the dry-subsurface layer of the Mount Feather Diamicton is acting as a trap for aeolian transported particles and possibly also meteorite ejecta (Gersonde et al., 1997) in the subsequent dry climate.

\section{Conclusions}

The Mount Feather Diamicton (Wilson and Barron, 1998) is defined as a separate formation of the Sirius Group using field observations, stratigraphic coring and analysis of core samples. It is solely a subglacial facies, deposited by a wetbased glacier, and now crops out at much higher elevation than other stratified Sirius Group strata reported from the Beardmore Glacier and Reedy Glacier areas (Webb et al., 1996; Wilson et al., 1998c), which contain glacilacustrine, glacifluvial and glacimarine as well as subglacial facies. The Mount Feather Diamicton records glacio-climatic information from the time of deposition, information about the environment prior to its deposition 
(from enclosed exotic clasts), and information about climatic conditions since deposition from periglacial drying and infilling of its surface layer above the permafrost boundary (Fig. 6). It also contains abundant ice that fills pore spaces and occurs as discrete horizons, which suggests stability and continued cold of the deposit since deposition despite its surface runnelling.

Most of the sediment comprising the Mount Feather Diamicton was derived locally. However, distinct palynomorph, phytolith and diatom assemblages demonstrate a more distal origin for a small exotic component of the deposit. Diatoms are distributed throughout the deposit but they are very rare and their occurrence is patchy. Surface assemblages may have been derived from aeolian processes. Marine diatoms recovered at depth in the deposit may have been derived from beneath the East Antarctic ice sheet and transported by glacial processes, but their occurrence is too rare to allow any definitive conclusion. With greater abundances, it may be possible to use the characteristics of the diatom assemblages to identify and constrain the input from each of these distinct sources.

The best age estimate for the Mount Feather Diamicton comes from the near-in situ non-marine diatom assemblage from $90 \mathrm{~cm}$ depth in COMRAC 10. This assemblage is excellently preserved and dominated by Anomoeoneis costata but also contains Stephanodiscus sp., which is a form known only from the Late Miocene-Present. This suggests that more temperate climatic conditions persisted in the region of Mount Feather until at least the Late Miocene, which is at odds with interpretations of the geomorphology of nearby regions.

\section{Acknowledgements}

The workshop was supported by NSF award OPP-9634644 to G.S.W. The cores were obtained as part of a collaborative project between E.I.F. and G.S.W. supported by NSF awards OPP9420227 (E.I.F.) and OPP-9420260 (G.S.W.). R.A.A. was supported by NSF awards OPP9418093 and OPP-9753000. D.M.H. and S.A.R. were supported by NSF award OPP-9158075. J.J.M.v.M., J.F.H. and A.P.S. acknowledge Frans Backer for preparing thin sections. Peter Barrett and Warren Dickinson provided discussion that improved an early draft of the manuscript. We are also grateful to Mark Mabin and Michael Hambrey for thorough and constructive reviews.

\section{References}

Askin, R.A., 1998. Palynological investigations of Mount Feather Sirius Group samples: Recycled Triassic assemblages. In: Wilson, G.S., Barron, J.A. (Eds.), Mount Feather Sirius Group Core Workshop and Collaborative Sample Analysis. BPRC Report No. 14, Byrd Polar Research Center, Ohio State University, Columbus, OH, pp. 59-65.

Barrett, P.J., 1998. Grain-size analysis of diamicton samples from Mount Feather. In: Wilson, G.S., Barron, J.A. (Eds.), Mount Feather Sirius Group Core Workshop and Collaborative Sample Analysis. BPRC Report No. 14, Byrd Polar Research Center, Ohio State University, Columbus, OH, pp. 66-68.

Barrett, P.J., Hambrey, M.J., 1992. Plio-Pleistocene sedimentation in Ferrar Fjord, Antarctica. Sedimentology 39, 109123.

Barrett, P.J., Powell, R.D., 1982. Middle Cenozoic glacial beds at Table Mountain, southern Victoria Land. In: Craddock, C. (Ed.), Antarctic Geoscience. University of Wisconsin Press, Madison, WI, pp. 1059-1067.

Barrett, P.J., Adams, C.J., McIntosh, W.C., Swisher, C.C., III, Wilson, G.S., 1992. Geochronological evidence supporting Antarctic deglaciation three million years ago. Nature 359, 816-818.

Barrett, P.J., Bleakley, N.L., Dickinson, W.W., Hannah, M.J., Harper, M.A., 1997. Distribution of siliceous microfossils on Mount Feather, Antarctica, and the age of the Sirius Group. In: Ricci, C.A. (Ed.), The Antarctic Region, Geological Evolution and Processes. Terra Antarctica Publication, Sienna, pp. 763-770.

Brady, H.T., McKelvey, B.C., 1979. The interpretation of a Tertiary Tillite at Mount Feather, southern Victoria Land, Antarctica. J. Glaciol. 22, 189-193.

Burckle, L.H., Pokras, E.M., 1991. Implications of a Pliocene stand of Nothofagus (southern beech) within 500 kilometers of the South Pole. Antarct. Sci. 3, 235-238.

Burckle, L.H., Potter, N., Jr., 1996. Pliocene-Pleistocene diatoms in Paleozoic and Mesozoic sedimentary and igneous rocks from Antarctica: A Sirius problem solved. Geology 24, 235-238.

Burckle, L.H., Stroeven, A.P., Bronge, C., Miller, U., Wasell, A., 1996. Deficiencies in the diatom evidence for a Pliocene reduction of the East Antarctic ice sheet. Paleoceanography 11, 379-389.

Carter, J.A., 1998. Phytolith Report of Mount Feather Cores. 
In: Wilson, G.S., Barron, J.A. (Eds.), Mount Feather Sirius Group Core Workshop and Collaborative Sample Analysis. BPRC Report No. 14, Byrd Polar Research Center, Ohio State University, Columbus, OH, pp. 69-74.

Carter, J.A., 1998b. Phytoliths from CRP-1. Terra Antarct. 5, 571-576.

Carter, J.A., 1999. Late Devonian, Permian and Triassic phytoliths from Antarctica. Micropaleontology 45, 56-61.

Denton, G.H., Prentice, M.L., Kellogg, D.E., Kellogg, T.B., 1984. Late Tertiary history of the Antarctic ice sheet: Evidence from the Dry Valleys. Geology 12, 263-267.

Denton, G.H., Prentice, M.L., Burckle, L.H., 1991. Cainozoic history of the Antarctic ice sheet. In: Tingey, R.J. (Ed.), The Geology of Antarctica. Clarendon Press, Oxford, pp. 365433.

Dickinson, W., 1998, Modal analysis of COMRAC samples Mount Feather. In: Wilson, G.S., Barron, J.A. (Eds.), Mount Feather Sirius Group Core Workshop and Collaborative Sample Analysis. BPRC Report No. 14, Byrd Polar Research Center, Ohio State University, Columbus, OH, pp. $74-76$.

Gersonde, R., Kyte, F.T., Bleil, U., Diekmann, B., Flores, J.A., Gohl, K., Grahl, G., Hagen, R., Kuhn, G., Sierro, F.J., Volker, D., Abelmann, A., Bostwick, J.A., 1997. Geological record and reconstruction of the late Pliocene impact of the Eltanin asteroid in the Southern Ocean. Nature 390, 357-363.

Hambrey, M.J., McKelvey, B.C., 2000. Major Neogene fluctuations of the East Antarctic ice sheet: Stratigraphic evidence from the Lambert Glacier region. Geology 28, 887890.

Harper, M.A., 1998. Report on diatoms in phytolith preparations from COMRAC cores, Mount Feather, Antarctica. In: Wilson, G.S., Barron, J.A. (Eds.), Mount Feather Sirius Group Core Workshop and Collaborative Sample Analysis. BPRC Report No. 14, Byrd Polar Research Center, Ohio State University, Columbus, OH, pp. 76-79.

Harwood, D.M., 1983. Diatoms from the Sirius Formation, Transantarctic Mountains. Antarct. J. US 18, 98-100.

Harwood, D.M., 1986. Recycled siliceous microfossils from the Sirius Formation. Antarct. J. US 21, 101-103.

Harwood, D.M., Rose, S.A., 1998. Report on diatom analysis of Mount Feather COMRAC cores. In: Wilson, G.S., Barron, J.A. (Eds.), Mount Feather Sirius Group Core Workshop and Collaborative Sample Analysis. BPRC Report No. 14, Byrd Polar Research Center, Ohio State University, Columbus, OH, pp. 79-89.

Harwood, D.M., Webb, P.-N., 1998. Glacial transport of diatoms in the Antarctic Sirius Group: Pliocene refrigerator. GSA Today $8,1-8$.

Harwood, D.M., Grant, M., Karrer, M., 1986. Techniques to improve microfossil recovery from glacial sediments. Antarct. J. US 21, 107-108.

Ishman, S.E., Rieck, H.J., 1992. A late Neogene Antarctic glacio-eustatic record, Victoria Land Basin margin, Antarctica. In: Kennett, J.P., Warnke, D.A. (Eds.), The Antarctic Paleoenvironment: A perspective on Global Change, Part 1.
Antarctic Research Series 56, American Geophysical Union, Washington, DC, pp. 327-348.

Kellogg, D.E., Kellogg, T.B., 1996. Diatoms in South Pole ice: Implications for eolian contamination of Sirius Group deposits. Geology 24, 115-118.

Kennett, J.P., Hodell, D.A., 1993. Evidence for relative climatic stability of Antarctica during the early Pliocene: A marine perspective. Geogr. Ann. 75A, 205-220.

Kondo, R., Childs, C.W., Atkinson, I.A.E., 1994. Opal Phytoliths of New Zealand. Landcare Research New Zealand.

Krebs, W.N., Bradbury, J.P., 1995. Geologic ranges of lacustrine Actinocyclus species, Western United States. In: Platt, B.J., Krebs, W.N. (Eds.), The Diatom Genus Actonocyclus in the Western United States. US Geological Survey Professional Paper, pp. 53-67.

Kyle, R.A., 1977. Palynostratigraphy of the Victoria Group of south Victoria Land, Antarctica. N.Z. J. Geol. Geophys. 20, 1081-1102.

Kyle, R.A., Schopf, J.M., 1982. Permian and Triassic palynostratigraphy of the Victoria Group, Transantarctic Mountains. In: Craddock, C. (Ed.), Antarctic Geoscience. University of Wisconsin Press, Madison, WI, pp. 649-659.

Marchant, D.R., Denton, G.H., Swisher, C.C., III, Potter, N., Jr., 1996. Late Cenozoic Antarctic paleoclimate reconstructed from volcanic ashes in the Dry Valleys. Geol. Soc. Am. Bull. 108, 181-194.

Marchant, D.R., Swisher, C.C., III, Lux, D.R., West, D., Jr., Denton, G.H., 1993. Pliocene paleoclimate and East Antarctic ice sheet history from surficial ash deposits. Science 260, 667-670.

Mayewski, P.A., 1972. Glacial geology near McMurdo Sound and comparison with the central Transantarctic Mountains. Antarct. J. US 7, 103-106.

Mayewski, P.A., 1975. Glacial geology and late Cenozoic history of the Transantarctic Mountains, Antarctica. Ohio State University Institute of Polar Studies Report 56, 186 pp.

McKelvey, B.C., Stephenson, N.C.N., 1990. A geological reconnaisance of the Radok Lake area, Amery Oasis, Prince Charles Mountains. Antarct. Sci. 2, 53-60.

McKelvey, B.C., Mercer, J.H., Harwood, D.M., Stott, L.D., 1984. The Sirius Formation: Further considerations. Antarct. J. US 19, 42-43.

McKelvey, B.C., Webb, P.-N., Harwood, D.M., Mabin, M.C.G., 1987. The Dominion Range Sirius Group: A record of the late Pliocene-early Pleistocene Beardmore Glacier. Fifth International Symposium on Antarctic Earth Sciences, Cambridge, p. 97.

McKelvey, B.C., Webb, P.-N., Harwood, D.M., Mabin, M.C.G., 1991. The Dominion Range Sirius Group: A record of the late Pliocene-early Pleistocene Beardmore Glacier. In: Thomson, M.R.A., Crame, J.A., Thomson, J.W. (Eds.), Geological Evolution of Antarctica. Cambridge University Press, Cambridge, pp. 675-682.

Mercer, J.H., 1968. Glacial geology of the Reedy Glacier area, Antarctica. Geol. Soc. Am. Bull. 79, 471-486.

Miller, M.F., Mabin, M.C.G., 1998. Antartic Neogene Land- 
scapes - In the refridgerator or in the deep freeze? GSA Today 8, 103.

Prentice, M.L., Denton, G.H., Lowell, T.V., Conway, H.C., Heusser, L.E., 1986. Pre-late Quaternary glaciation of the Beardmore Glacier region, Antarctica. Antarct. J. US 21, 95-98.

Stroeven, A.P., Prentice, M.L., 1997. A case for Sirius Group alpine glaciation at Mount Felming, South Victoria Land, Antarctica; a case against Pliocene East Antarctic ice sheet reduction. Geol. Soc. Am. Bull. 109, 825-840.

Stroeven, A.P., Prentice, M.L., Kleman, J., 1996. On marine microfossil transport and pathways in Antarctica during the late Neogene: Evidence from the Sirius Group at Mount Fleming. Geology 24, 727-730.

Stroeven, A.P., Burckle, L.H., Kleman, J., Prentice, M.L., 1998. Atmospheric transport of diatoms in the Sirius Group: Pliocene deepfreeze. GSA Today 8, 1-5.

Stroeven, A.P., van der Meer, J.J.M., Stroeven, P., Dalhuisen, D.H., Hiemstra, J.F., Stroeven, M., in press. Improved microfabric determination using stereological analysis: Orientation direction of sand particles in Mount Feather Sirius Group tillite, Antarctica. Proceedings of the eighth International Symposium on Antarctic Earth Sciences, Wellington.

Sugden, D.E., 1996. The East Antarctic ice sheet: Unstable ice or unstable ideas? Trans. Inst. Br. Geogr. NS21, 443454.

Sugden, D.E., 1999. Landscape development in the Royal Society Range, southern Victoria Land, Antarctica: Stability since the mid-Miocene. Geomorphology 28, 181-200.

Sugden, D.E., Marchant, D.R., Denton, G.H., 1993. The case for a stable East Antarctic ice sheet. Geogr. Ann. 75A, 151331.

Sugden, D.E., Denton, G.H., Marchant, D.R., 1995. Landscape evolution of the Dry Valleys, Transantarctic Mountains. J. Geophys. Res. 100 (B7), 9949-9967.

van der Meer, J.J.M., Hiemstra, J.F., Stroeven, A.P., 1998. Micromorphology of two Sirius Group core diamict samples from Mt. Feather, Dry Valleys, Antarctica. In: Wilson, G.S., Barron, J.A. (Eds.), Mount Feather Sirius Group Core Workshop and Collaborative Sample Analysis. BPRC Report No. 14, Byrd Polar Research Center, Ohio State University, Columbus, OH, pp. 96-108.

Webb, P.-N., 1994. Paleo-drainage systems of East Antarctica and sediment supply to West Antarctic rift system basins. Terra Antart. 1, 457-461.

Webb, P.-N., Harwood, D.M., 1987. Terrestrial flora of the
Sirius Formation. Its significance for Late Cenozoic glacial history. Antarct. J. US 22, 7-11.

Webb, P.-N., Harwood, D.M., 1991. Late Cenozoic glacial history of the Ross Embayment, Antarctica. Quat. Sci. Rev. 10, 215-223.

Webb, P.-N., Harwood, D.M., McKelvey, B.C., Mercer, J.H., Stott, L.D., 1984. Cenozoic marine sedimentation and ice volume variation on the East Antarctic craton. Geology 12, 287-291.

Webb, P.-N., Harwood, D.M., McKelvey, B.C., Mabin, M.C.G., Mercer, J.H., 1986. Late Cenozoic tectonic and glacial history of the Transantarctic Mountains. Antarct. J. US 21, 99-100

Webb, P.-N., Harwood, D.M., Mabin, M.C.G., McKelvey, B.C., 1996. A marine and terrestrial Sirius Group succession, middle Beardmore Glacier-Queen Alexandra Range, Transantarctic Mountains, Antarctica. Mar. Micropaleontol. 27, 273-297.

Wilson, G.S., 1995. The Neogene Antarctic ice sheet: A dynamic or stable feature? Quat. Sci. Rev. 14, 101-123.

Wilson, G.S., Barron, J.A., 1998. Mount Feather Sirius Group Core Workshop and Collaborative Sample Analysis. BPRC Report No. 14, Byrd Polar Research Center, Ohio State University, Columbus, OH, $122 \mathrm{pp}$.

Wilson, G.S., Braddock, P., Foreman, S.L., Friedman, E.I., Rivkina, E.M., Chanton, J.P., Gilichinsky, D.A., Fyodorov-Davidov, D.G., Ostroumov, V., Sorokovikov, V., Wizevich, M.C., 1996. Coring for microbial record of Antarctic climate. Antarct. J. US 31, 83-86.

Wilson, G.S., Curren, M., Wizevich, M.C., 1998. The FSU Antarctic Core Repository clean room. In: Wilson, G.S., Barron, J.A. (Eds.), Mount Feather Sirius Group Core Workshop and Collaborative Sample Analysis. BPRC Report No. 14, Byrd Polar Research Center, Ohio State University, Columbus, $\mathrm{OH}$, pp. 9-11.

Wilson, G.S., Friedman, E.I., Rivkina, E.M., Gilichinsky, D.A., Fyodorov-Davidov, D.G., Ostroumov, V.E., Sorokovikov, V., Wizevich, M.C., Chanton, J.P., 1998. Viable microbes from Mount Feather COMRAC cores. In: Wilson, G.S., Barron, J.A. (Eds.), Mount Feather Sirius Group Core Workshop and Collaborative Sample Analysis. BPRC Report No. 14, Byrd Polar Research Center, Ohio State University, Columbus, OH, pp. 109-110.

Wilson, G.S., Harwood, D.M., Askin, R.A., Levy, R.H., 1998c. Late Neogene Sirius Group strata in Reedy Valley, Antarctica: A multiple-resolution record of climate, icesheet and sea-level events. J. Glaciol. 44, 437-447. 